\title{
REDUCED ISOTROPIC CRYSTAL MODEL WITH RESPECT TO THE FOURTH-ORDER ELASTIC MODULI
}

\author{
O. Burlayenko, V. Khodusov, A. Naumovets \\ Kharkov V.N. Karazin National University \\ Sq. Svobody 4, Kharkov, 61022, Ukraine \\ E-mail:vkhodusov@ukr.net \\ Received March 1, 2018
}

Using a reduced isotropic crystal model the relationship between the fourth-order elastic moduli of an isotropic medium and the independent components of the fourth-order elastic moduli tensor of real crystals of various crystal systems is found. To calculate the coefficients of these relations, computer algebra systems Redberry and Mathematica for working with high order tensors in the symbolic and explicit form were used, in light of the overly complex computation. In an isotropic medium, there are four independent fourth order elastic moduli. This is due to the presence of four invariants for an eighth-rank tensor in the threedimensional space, that has symmetries over the pairs of indices. As an example, the moduli of elasticity of an isotropic medium corresponding to certain crystals of cubic system are given ( $\mathrm{LiF}, \mathrm{NaCl}, \mathrm{MgO}, \mathrm{CaF}_{2}$ ). From the obtained results it can be seen that the reduced isotropic crystal model can be most effectively applied to high-symmetry crystal systems.

KEY WORDS: fourth order elastic moduli, cubic crystal system, isotropic crystal, phonon interaction

\section{МОДЕЛЬ ЗВЕДЕНОГО ІЗОТРОПНОГО КРИСТАЛА ВІДНОСНО МОДУЛІВ ПРУЖНОСТІ ЧЕТВЕРТОГО ПОРЯДКУ \\ О. Бурласнко, В. Ходусов, А. Наумовець}

Харківський національний університет ім. В.Н. Каразіна

пл. Свободи, 4, м. Харків, 61022, Україна

У статті за допомогою моделі зведеного ізотропного кристала знайдений зв'язок модулів пружності четвертого порядку ізотропного середовища 3 незалежними компонентами тензора модулів пружності четвертого порядку реальних кристалів різних сингоний. Для розрахунку коефіцієнтів, що задають ці зв'язки , використовувалися системи комп'ютерної алгебри по роботі з тензорами вищих порядків в символьному і явному вигляді Redberry i Mathematica, зважаючи на значну громіздкість обчислень. В ізотропному середовищі є чотири незалежних модулів пружності четвертого поряд. Це пов'язано 3 наявністю чотирьох інваріантів у тензора восьмого рангу в тривимірному просторі, який має симетрії по парам індексів. Як приклад наведено модулі пружності ізотропного середовища, що відповідає деяким кристалам кубічної сингонії (LiF, $\left.\mathrm{NaCl}, \mathrm{MgO}, \mathrm{CaF}_{2}\right) .3$ отриманих результатів видно, що модель зведеного ізотропного кристала може бути найбільш ефективно застосована для кристалів сингоний високих симетрій.

КЛЮЧОВІ СЛОВА: модулі пружності четвертого порядку, кубічна сингонія, ізотропний кристал, взаємодія фононів

\section{МОДЕЛЬ ПРИВЕДЕННОГО ИЗОТРОПНОГО КРИСТАЛЛА ОТНОСИТЕЛЬНО} МОДУЛЕЙ УПРУГОСТИ ЧЕТВЕРТОГО ПОРЯДКА

\section{А. Бурлаенко, В. Ходусов, А. Наумовец}

Харьковский национальный университет им. В.Н. Каразина

пл. Свободы, 4, г. Харьков, 61022, Украина

В статье с использованием модели приведенного изотропного кристалла найдена связь модулей упругости четвертого порядка изотропной среды с независимыми компонентами тензора модулей упругости четвертого порядка реальных кристаллов различных сингоний. Для расчета коэффициентов задающих эти связи использовались системы компьютерной алгебры по работе с тензорами высших порядков в символьном и явном виде Redberry и Маthematica, ввиду крайней громоздкости вычислений. В изотропной среде имеется четыре независимых модуля упругости четвертого порядка. Это связано с наличием четырех инвариантов у тензора восьмого ранга в трехмерном пространстве, обладающего симметриями по парам индексов. В качестве примера приведены модули упругости изотропной среды соответствующей некоторым кристаллам кубической сингонии ( $\mathrm{LiF}, \mathrm{NaCl}, \mathrm{MgO}, \mathrm{CaF}_{2}$ ). Из полученных результатов видно, что модель приведенного изотропного кристалла наиболее эффективно работает для кристаллов сингоний высоких симметрий.

КЛЮЧЕВЫЕ СЛОВА: модули упругости четвертого порядка, кубическая сингония, изотропный кристалл, взаимодействие фононов

There exist some physical phenomena in crystals that cannot be described without taking into account the interaction of phonons with each other. In particular, the thermal expansion of a solids, the kinetic phenomena of thermal conductivity, the viscosity etc. can be related to such cases. If one takes into consideration these interactions for real crystals, significant difficulties occur.

As low-frequency phonon oscillations play the main role in the abovementioned phenomena in a solid, it is possible to use the macroscopic theory of elasticity. In this model, a crystal is replaced by the continuous medium possessing the symmetry of the crystal lattice [1]. 
The purpose of this paper is to calculate the fourth order elastic coefficients of an isotropic medium, that corresponds most closely to a real crystal, in relation to its elastic properties. These coefficients are needed to explanation of nonlinear phenomena in solids.

\section{JUSTIFICATION FOR THE MODEL}

The free energy is represented as an expansion in terms of a small strain tensor as follows:

$$
F=F_{0}+\frac{1}{2} \lambda_{i j k l} u_{i j} u_{k l}+\frac{1}{6} \lambda_{i j k l m n} u_{i j} u_{k l} u_{m n}+\frac{1}{24} \lambda_{i j k l m n p q} u_{i j} u_{k l} u_{m n} u_{p q},
$$

where $u_{i k}=\frac{1}{2}\left(\nabla_{i} u_{k}+\nabla_{k} u_{i}+\nabla_{i} u_{l} \nabla_{k} u_{l}\right)$ - strain tensor, $\lambda_{i j k l}, \lambda_{i j k l m n}, \lambda_{i j k l m n p q}$ are the tensors of elastic moduli of the 4th, 6th and 8 th rank, respectively.

If solid is considered as an isotropic medium, the thermodynamic and kinetic coefficients are calculated most simply. Some attempts to reduce the real crystal to an isotropic medium were first done within the Debye model and, then, was developed in the theory of elasticity [2]. For this sake, the second order elastic moduli $\lambda$ and $\mu$ and the third order elastic moduli A, B and C were used. A model of an isotropic crystal with elastic properties closest to the real one was suggested in the work [3]. According to the paper [4], we will call this model a reduced isotropic crystal model (RICM) with respect to the elastic moduli. Also, a procedure of calculating of the elastic moduli of the reduced isotropic crystal through the elastic moduli of the real crystal was described there. It turns out that RICM corresponds most of all to a real crystal not only with respect to the elastic waves that propagate in it, but also to any elastic properties in general. The use of this model for the second and third order elastic moduli for calculation of the Debye's temperature and for calculation of phonon viscosity and thermal conductivity yields a result which is in a good agreement with the experiment [4].

However, it is still necessary to take into account the fourth order elastic moduli (FOEM) in the reduced isotropic crystal model for calculations of the Grünisen parameter of a real crystal and the influence of the phonons interaction on the thermodynamic properties of crystals [5]. In the case of an isotropic medium the tensor of elastic moduli of the 8th rank has 4 independent components D, E, F, G [6].

Using a minimization procedure for the expression $\left|\lambda_{i k l m n p q t}^{(\mathrm{Re})}-\lambda_{i k l m n p q t}^{(0)}\right|^{2}$ by $\mathrm{D}, \mathrm{E}, \mathrm{F}, \mathrm{G}$, one may obtain their connection with FOEM of a real crystal. Here $\lambda_{i k l m n p q t}^{(0)}$ is the 8 th rank tensor of elastic moduli of an isotropic medium, the explicit form of which is given in [5]. It has four invariants [7]. The expansion into a series of the free energy of a crystal includes a convolution of FOEM tensor with the product of four strain tensors. This convolution is expressed by $\lambda_{i k l m n p q t}^{(0)}$ invariants, that is why isotropic medium has four FOEC.

After the appropriate minimization procedure, we obtain the following expressions:

$$
\begin{aligned}
& D=\frac{1}{56700}\left(1123 \lambda_{\text {ilkkllpp }}-618 \lambda_{\text {iikklppl }}-2296 \lambda_{\text {iikllppk }}-1671 \lambda_{\text {ikkilppl }}+3522 \lambda_{\text {ikkllppi }}\right) \text {; } \\
& E=\frac{1}{113400}\left(-103 \lambda_{\text {iikklpp }}+438 \lambda_{\text {iikklppl }}+376 \lambda_{\text {iiklppk }}+411 \lambda_{\text {ikkilppl }}-1002 \lambda_{\text {ikkllppi }}\right) \text {; } \\
& F=\frac{1}{226800}\left(-287 \lambda_{i i k k l l p p}+282 \lambda_{\text {iikklppl }}+1184 \lambda_{\text {iikllppk }}+39 \lambda_{\text {ikkilppl }}-978 \lambda_{\text {ikkllppi }}\right) \text {; } \\
& G=\frac{1}{226800}\left(-557 \lambda_{i i k k l p p}+822 \lambda_{\text {iikklppl }}+104 \lambda_{\text {iikllppk }}+2469 \lambda_{i k k i l p p l}-2598 \lambda_{i k k l p p i}\right) \text {; }
\end{aligned}
$$

There is a sum from 1 to 3 over the repeated indices.

We shall carry out calculations for crystal systems of the highest symmetries as they have lower degree of anisotropy and are closer to an isotropic medium by their properties. Besides for crystals of these crystal systems, experimentally measured values of FOEM exist, using which one can obtain the elastic moduli of the reduced isotropic crystal. The expressions of coefficients D, E, F, G are given in Table. 1 (in Appendix). To receive values of D, E, F, G from the table, it is necessary to multiply the coefficients in a row by the corresponding values of FOEM $\mathrm{C}_{\mathrm{iklm}}$ presented in the matrix form and to sum them up. For example, for crystals of cubic crystal system, we obtain:

$$
D=\frac{1}{315}\left(c_{1111}+32 c_{1112}+36 c_{1122}+204 c_{1123}-132 c_{1144}-24 c_{1166}-312 c_{1244}-36 c_{1266}+240 c_{1456}+6 c_{4444}+12 c_{4466}\right) ;
$$




$$
\begin{gathered}
E=\frac{1}{315}\left(c_{1111}+14 c_{1112}+9 c_{1122}-3 c_{1123}+21 c_{1144}-6 c_{1166}+48 c_{1244}-48 c_{1456}-3 c_{4444}-6 c_{4466}\right) ; \\
F=\frac{1}{630}\left(2 c_{1111}+10 c_{1112}-9 c_{1122}-24 c_{1123}+6 c_{1144}+6 c_{1166}+78 c_{1244}+36 c_{1266}-6 c_{1456}-15 c_{4444}-30 c_{4466}\right) ; \\
G=\frac{1}{630}\left(2 c_{1111}-8 c_{1112}+27 c_{1122}-42 c_{1123}+96 c_{1144}+24 c_{1166}+60 c_{1244}-54 c_{1266}-168 c_{1456}+39 c_{4444}+78 c_{4466}\right) .
\end{gathered}
$$

Let us display the values of the second, third and fourth order elastic moduli, calculated on the basis of RICM model for some crystals of the cubic crystal system in Table. 2 (in Appendix), using experimentally measured elastic moduli given in works $[8,9]$.

Our next task is to analyze the calculated coefficients. In the paper [10] it was shown that from 6561 components of tensor $\lambda_{i k l m n p q t}^{(\mathrm{Re})}$ much less ones are independent. Let us write out the number of independent components (FOEM) for various crystal system: triclinic $(1, \overline{1})$ : 126 ; tetragonal $(4 \mathrm{~mm}, \overline{4} 2 \mathrm{~m}, 422,4 / \mathrm{m} 2 / \mathrm{m} \mathrm{2} 2 \mathrm{~m}): 25$; trigonal $(3 \mathrm{~m}, 32, \overline{3} 2 / \mathrm{m}): 28$; hexagonal $(\overline{6} 2 \mathrm{~m}, 6 \mathrm{~mm}, 622,6 / \mathrm{m} 2 / \mathrm{m} 2 / \mathrm{m}): 19$; cubic $(\overline{4} 3 \mathrm{~m}, 432,4 / \mathrm{m} \overline{3} 2 / \mathrm{m}): 11$. The number of the independent coefficients included in D, E, F, G of the reduced isotropic crystal for different crystal system are the following: triclinic: 36, tetragonal: 19, trigonal: 19, hexagonal: 13, cubic: 11 .

\section{CONCLUSIONS}

A simple comparison of the number FOEM tensor components of a real crystal with those included into coefficients D, E, F, G shows that the model of the reduced isotropic crystal describes rather well the properties of a real crystal, especially for a high symmetry crystal system.

If the values of FOEM are known for a real crystal, then it is possible to determine the values of coefficients D, E, $\mathrm{F}, \mathrm{G}$ for the model of a reduced isotropic crystal and the matrix elements of interaction of four phonons $\Phi(1,2,3,4)$, as well as to calculate to within a number the quantities that characterize various phenomena in crystals for which nonlinear interactions of phonons are essential.

\section{REFERENCES}

1. Tucker J.W. and Rampton V.W. Microwave Ultrasonics in Solid State Physics. - Amsterdam: North Holland, 1972. - 418p.

2. Landau L.D., Lifshitz E.M. Theory of Elasticity. - Oxford: Butterworth-Heinemann, 1986. - 187 p.

3. Fedorov F.I. Theory of Elastic Waves in Crystals. - New York: Plenum Press, 1968. -375 p.

4. Akhiezer A.I., Aleksin V.F., Khodusov V.D. Gas dynamics of quasi-particles // Low Temp. Phys. - 1994. - Vol.20. - P.939.

5. Poluektov Yu.M. Self-Consistent Description Of Interacting Phonons In A Crystal Lattice // East Eur. J. Phys. - 2016. - Vol. 3. - No.3. - P. 35-46.

6. Krishnamurty T.S.G. Fourth-order Elastic Coefficients in Crystals // Acta Cryst. - 1963. - Vol. 16. - P. 839-840.

7. Destradea M., Ogdenb R.W. On the third- and fourth-order constants of incompressible isotropic elasticity // The Journal of the Acoustical Society of America. - 2010. - Vol. 128. - P. 3334-3343.

8. Garg V.K., Puri D.S., Verma M.P. Many-Body Effects on the Fourth-Order Elastic Constants of Ionic Solids // Phys. Stat. Sol. (b). - 1977. - Vol. 82. - P. 325-334.

9. Goyal S.C., Sharma A.K. Fourth-Order Elastic Constants of Fluorite Structure Solids // Phys. Stat. Sol. (b). - 1988. - Vol. 146. - P. 435-443.

10. Krishnamurty T.S.G., Gopalakrishnamurty P. Elastic coefficients in crystals // Acta Cryst. - 1968. - Vol. 24. - P. 563-565. 


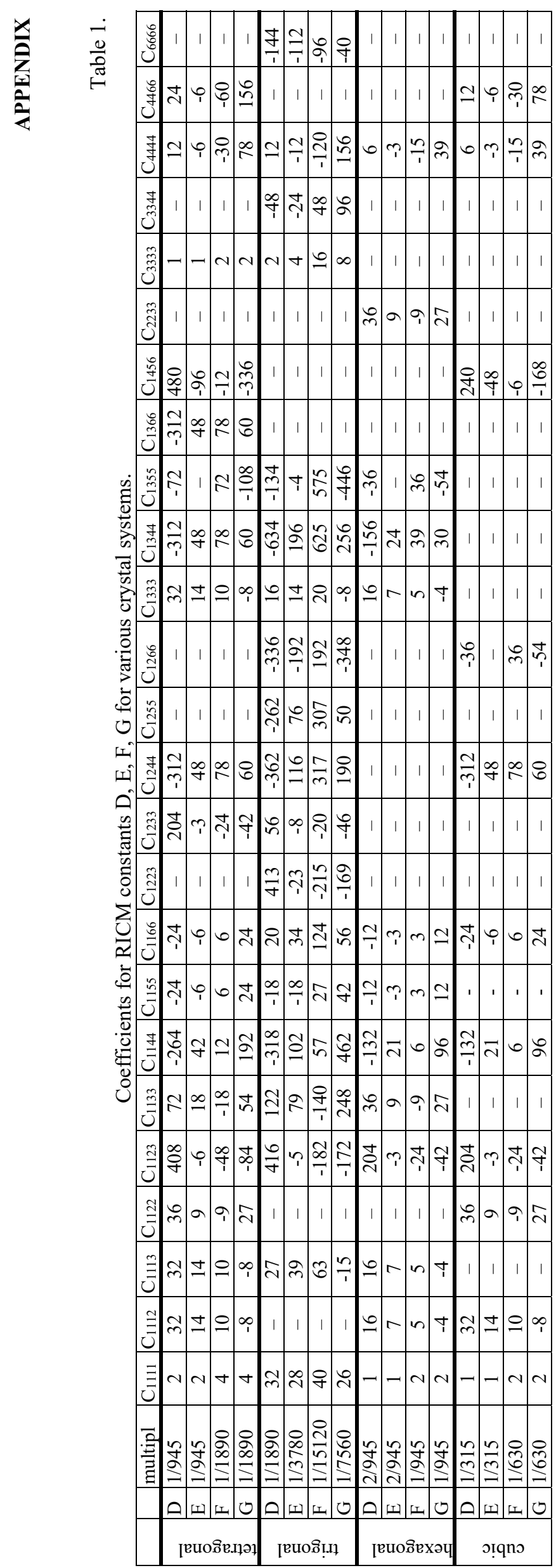

光

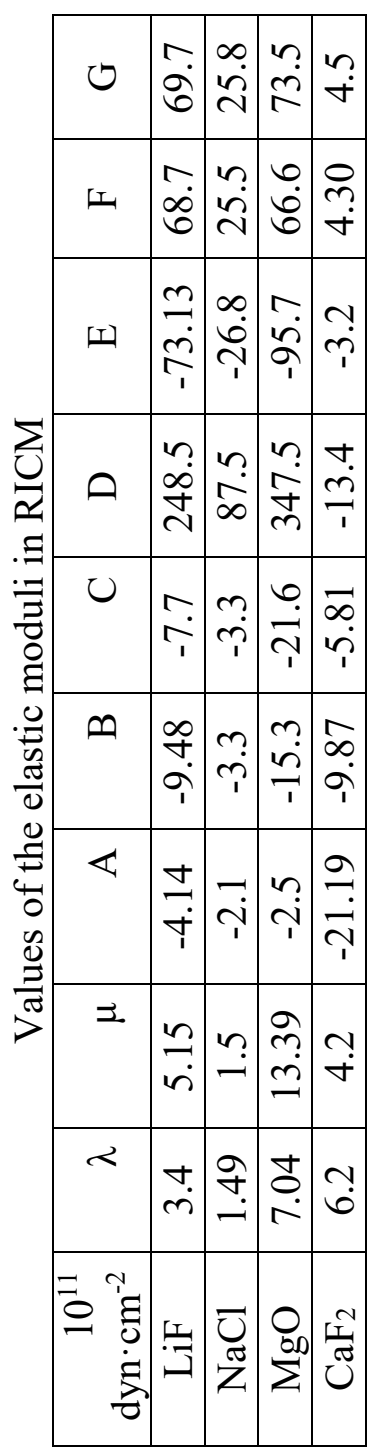

